Educational Administration: Theory and Practice

2014, Vol. 20, Issue 1, pp: 47-69

Kuram ve Uygulamada Ë̆itim Yönetimi

2014, Cilt 20, Sayı 1, ss: 47-69

$w w w . k$ u ey, net

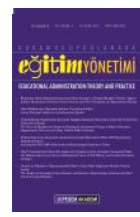

AKADEMI

\title{
Okul Müdürlerinin Etik Liderlik Davranışları ile Öğretmenlerin İş Doyumlarının Örgütsel Bağlılıkla İlişkisi
}

\section{Relationships of School Principals' Ethical Leadership and Teachers' Job Satisfaction on Teachers' Organizational Commitment}

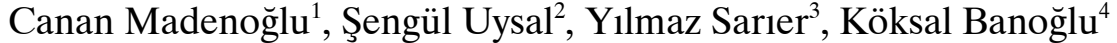

$\ddot{O} \mathbf{z}$

$\mathrm{Bu}$ araştırmanın amacı ortaöğretim kurumlarında (Anadolu lisesi, fen lisesi, meslek lisesi) çalışan öğretmenlerin görüşlerine göre, okul müdürlerinin etik liderliği, öğretmenlerin iş doyumu ve öğretmenlere ait demografik değiskenlerinin örgütsel bağglılı̆ı yordama düzeyini ortaya koymaktır. Araştırma ilişkisel tarama modeline dayanan betimsel bir çalışmadır. Araştırma evrenini, 2011-2012 eğitim-öğretim yılında Eskişehir ilinin merkez ilçelerinde (Odunpazarı ve Tepebaşı) resmi ortaöğretim kurumlarında (Anadolu lisesi, fen lisesi, meslek lisesi) görev yapan öğretmenler oluşturmaktadır. Evren ulaşılabilir olduğu için ayrıca örneklem alınmamış ve 940 öğretmenden toplanan veriler araştırmaya dahil edilmiş̧ir. Araştırma sonucunda öğretmenlerin örgütsel bağlllık düzeyini, okul müdürlerinin etik liderlik ve öğretmenlerin iş doyumu değişkenlerinin yordayıcısı olduğu tespit edilmiştir. Ayrıca cinsiyet ve okul türü değişkenlerinin de örgütsel bağlılı̆̆ yordadığı belirlenmiştir. Diğer bir ifadeyle, Anadolu lisesinde görev yapan erkek öğretmenlerin is doyumunda ve okul yöneticilerinde algıladıkları etik liderlik düzeyi örgütsel bağlılık düzeyinin bir yordayıcısıdır. Hiyerarşik regresyon analizi sonucunda, okul yöneticilerinin etik liderlik davranışlarının temel yordayıcı değişken olduğu, iş doyumunun ise örgütsel bağlılık üzerinde aracı değişken olduğu görülmüsstür.

Anahtar sözcükler: Etik liderlik, örgütsel bağlılık, iş doyumu, regresyon analizi, aracı değişken

\begin{abstract}
The purpose of this research is to investigate the effect of school principals' ethical leadership behaviors and teachers' job satisfaction over the predictability level of teachers' organizational commitment. The current research is a descriptive study based on the relational model. The research population consists of 1220 teachers working at secondary public schools (Anatolin high school, science high school, vocational high school) located in Eskişehir downtown (Odunpazarı and Tepebasi districts). Seeing that the research population was accessible, no spesific sample method was used for data selection. After removing out the missing questionnaires, 940 teachers were included in this study. The research concluded that ethical leadership and teachers' job satisfaction are predictor variables which have the biggest effect on teachers' organizational commitment. Additionally, it was found that gender and school type variables predict teachers' organizational commitment to a small extent. That is, when job satisfaction perception of male teachers working at Anatolian high school and ethical leadership increase, their organizational commitment perception is predictable associated with the increase concerned. Besides, the results evidenced that ethical leadership behaviors of school administrators is the main predictor to explain teachers' job satisfaction while job satisfaction functions as a mediating variable of the relationship between ethical leadership and organizational commitment variables.
\end{abstract}

Keywords: Ethical leadership, job satisfaction, organizational commitment, regression analysis, mediating variable

${ }^{1} \mathrm{PhD}$, Salih Zeki Anadolu Lisesi, İstanbul, cmadenoglu@gmail.com, ${ }^{2}$ Eskişehir Osmangazi Üniversitesi, Eskişehir, uysalsengul@yahoo.com.tr, ${ }^{3}$ Eskişehir Osmangazi Üniversitesi, Eskişehir, yilmazsarier@yahoo.com, ${ }^{4}$ Istanbul Halit Armay Anadolu Sağlık Meslek Lisesi, İstanbul, koksal_banoglu@hotmail.com

Atıf için/Please cite as:

Madenoğlu, C., Uysal, Ș., Sarıer, Y., \& Banoğlu, K. (2014). Okul müdürlerinin etik liderlik davranışları ile öğretmenlerin iş doyumlarının örgütsel bağlılıkla ilişkisi. Kuram ve Uygulamada Eğitim Yönetimi [Educational Administration: Theory and Practice], 20(1), 47-69. doi: 10.14527/kuey.2014.003 
Liderlik ile ilgili çok sayıda kuramsal ve deneysel araştırma yapılmıştır. Söz konusu araştırmaların bir bölümünde liderlik özelliklerini, davranış ve güç kaynakları incelenirken (Lee, 1977; Rahim, 2004) bazılarında ise liderlik etki alanları ile örgütsel sonuçları arasındaki ilişki araştırılmıştır (Amabile, 1998; Hipp ve Bredeson, 1995; Korkmaz, 2007; Zhu, 2008). Liderlik davranışları ve izlediği stratejiler, örgüt amaçlarının gerçekleştirilmesi ile izleyicilerin değer, inanç ve davranışlarını etkilemektedir. Diğer örgütlerde olduğu gibi eğitim örgütü yöneticilerinin liderlik özellikleri de eğitim bilim araştırmacılarını meşgul eden konuların başında gelmektedir. Okul müdürlerinin liderlik davranışları ve özelliklerine ilişkin çok sayıda araştırma yapılmasına karşın, bu konuda tam bir görüş birliğinin olduğunu söylemek mümkün değildir.

Sorulması gereken sorulardan bir tanesi 'her yönetici bir lider midir?' sorusudur. Bu soruya Hameck (1970) her liderin az çok bir yönetici olabileceğini, ancak her yöneticinin bir lider olmasının mümkün olmadığını belirterek cevap vermiştir. Liderlik ile ilgili çok sayıda tanım yapılmış, lider ve yönetici arasındaki farklar ortaya koyulmaya çalışılmışır. Peter Drucker'ın belirttiği gibi, liderliğin temel amacı, ortak bir hedefe yönelik çalışma aracılığıyla bir arada bulunan bir insan topluluğu yaratmaktır (akt. Bennis, 1989). Çünkü liderlik ve yöneticilik özdeş olmayan ancak birbirini tamamlayan düşünce ve eylemleri içeren kavramlardır (Çırpan, 1999; Özden, 2002).

Eğitim yönetimi literatürü incelendiğinde, çok sayıda liderlik türü olduğu görülmektedir. Etik liderlik son zamanlarda örgütsel davranış ve yönetim boyutunda özellikle bireysel grup ve örgütsel çıktılara etkisi açısından eğitim bilimciler tarafından tartışılmaktadır (Dale ve Fox, 2008; Karagöz, 2008; Uğurlu ve Üstüner, 2011). Bu konu irdelenirken öncelikle üzerinde durulması gereken kavram 'etik' olmalıdır. Etik, Yunanca karakter anlamına gelen ethos kavramından gelmektedir. Ahlak ise Latince adet, gelenek anlamına gelen moralty kavramından gelmektedir. Etik kavramı daha çok bireylerin karakterlerine yönelik algılanırken, ahlakilik (morality) insanların birbirleriyle ilişkileri kapsamında kullanılmaktadır (Thiroux, 1998). Etik, bilinçli olarak yapılan insan eylemlerinin doğru ya da yanlışlığını araştıran felsefi bir bilimdir (Werner, 1993). Etik değerlerin liderlik için önemi ve gerekliliği günümüzde ön plana çıkmış bir durum değildir. İnsanlık tarihi boyunca etiğin önemi ifade edilmiş, bir liderde bulunması beklenen etik değerler dile getirilmiştir. Örneğin ünlü düşünür Spinoza'ya göre kişi doğal ortamında tutkularının esiridir. Bu esaretten ancak aklın ve bilginin yardımı ile kurtulabilir. Bu nedenle Spinoza'ya göre akli davranmak ile ahlaklı davranmak aslında aynıdır (Aydın, 2004).

Diğer insanları amaçlar doğrultusunda bir araya getirme ve etkileme yeteneği olarak ifade edilebilecek liderlik, büyük titizlikle seçilmiş kişilik özellikleri ister. Bu özellikler tüm zamanlarda geçerli olan kişisel eylemlerden yani etik değerlerden oluşmalıdır (Calabrese, 1988). Çünkü etik değerler insanlık tarihi boyunca değişmeyen ve herkes tarafından yüceltilen özelliklerdir. 
Tarihi süreçte etik değerler, birlikte yaşamanın, doğru işler yapmanın, kaliteli insan olmanın ve çevresindeki izleyenlerini etkilemenin en başat aracı olmuştur.

Cuilla'ya (1998) göre etik liderlik, iyiliği yaymaya çalışmak, başkalarının kişisel özelliklerine saygı göstermek, dürüstlük, güvenirlilik, inanırlılık, samimilik, kişilerarası beceri, demokratik karar alma ve katılımı destekleme, anlayışlı ve kibar olma becerilerinin kombinasyonu olarak tanımlanabilir. Etik liderlik, liderin etik değerlere sahip olması ve davranışlarını bu etik değerlerle ilişkilendirerek ifade etmesidir (Cuilla, 1998). Greenfield (1991) etik lideri, öğretmenler üzerinde güçlü bir etki oluşturan, kendisine ve işine yönelik olarak moral bir bakış açısına sahip olan ve öğretmenlerin iş amaçlarını gerçekleştirmelerine yardım eden kişi olarak tanımlamaktadır (Çelik, 2003).

\section{Eğitim Yönetiminde Etik Liderlik}

Okul yöneticileri okulun liderleri olarak bir takım sorumluluklara sahiptirler. $\mathrm{Bu}$ sorumluluklar okuldaki eğitim ve öğretim sürecini etkilemektedirler. Bu sebeple etik ve ahlak onlar için önemlidir (Dobel, 1998). Okul gibi eğitim örgütlerinde liderler; özgürlük, dürüstlük, adalet ve eşitlik gibi önemli davranışları sergilemekten sorumludur. Bunları sergileyebilmek için, okul liderleri kendi değer sistemini bilmek zorundadır. Okul yöneticilerinin değer sistemi, eylemlerine yön verecek etik değerlerden oluşmalıdır (Crawford ve Nicklaus, 2000; Czaja ve Lowe, 2003). Sergiovanni ve Starratt'a (1998) göre, okul yöneticiliği bireysel açıdan etik üstünlüğü gerektirmektedir. Johnson (2000) tarafından yapılan bir araştırma eğitim liderliğinin dürüstlük, saygı duymak ve saygı görmek gibi erdemlerle ilgili olduğunu ve böyle liderlerin çalışanların gözünde değerli olduklarını göstermiştir (akt. Karaköse ve Kocabaş, 2009). Dolayısıyla okul yöneticileri, etik liderlik becerilerine sahip olmak ve bunları sergilemek zorundadır.

Rebore (2001) okul yöneticisinin etik lider olarak sahip olması gereken belli başlı özellikleri: toplumsal yapı içinde eğitim amacı ve liderin rollerinin bilgisine sahip olması; etik hakkında değişik bakış açıları ve değerler bilgisi; okulu daha iyi bir topluluk yapma konusunda istekli olması; kişisel ve mesleki değerleri inceleme konusunda istekli olması; etik değerleri ve inançları davranışlarla ifade etme konusunda diğer insanlara ilham vermesi; okuldaki işler için sorumluluğu kabul etmesi; eğitim amacını, kişisel kazancından daha üstün tutması; öğretmenlere eşit, adil ve saygılı davranması; yasal zorunluluklara dikkat etmesi; okulda çalışan diğer insanların etik değerlere bağlı davranmasını sağlaması; gerektiği yerde kanunlara ve yasalara başvurması olarak sıralamıştır.

Moorhouse (2002) eğitim kurumlarında çalışan bir etik liderde bulunması gereken değerleri tespit etmeyi amaçlayan bir çalışma yapmıştır. Bu çalışmanın sonunda, kurumlar için beş etik değerin, okul yöneticilerinde bulunması gereken yedi etik becerinin olduğu tespit edilmiştir. "Kurumun güvenilir, dürüst, adaletli olması, yüksek ahlaki standartlara bağlı kalması ve kurumun 
yaptığı işlerin amaçlarıyla ilişkili olması" özellikleri, kurumlar için ortaya konan beş temel etiksel özelliklerdir. Okul yöneticilerinde bulunması gereken yedi etik beceri ise, ahlaki davranışlarıyla izleyenlere örnek olma, güven ortamı oluşturma ve etkili iletişim kurma, vizyon geliştirme, dürüst olma, öğretmenleri karar alma sürecine katma ve son olarak takım oluşturmadır (Moorhouse, 2002). Quick ve Normore (2004)'a göre ise etik bir okul yöneticisi ahlaki bir vizyon belirlemeli, okul değerlerinin simgesi olmalı, davranışlarıyla izleyenlerine örnek oluşturmalı, karar ve yelemlerinin olası sonuçlarının bilincinde olmalıdır.

Okul yöneticilerinin etik liderlik becerileri iletişimsel, iklimsel, davranışsal ve karar vermede etik olmak üzere dört farklı boyutta ele alınmaktadır. İletişimsel etik, yönetici ve çalışanlar arasında sağlıklı iletişim ağının kurulması ve çalışanların iş doyumunun sağlanması ile ilgilidir. Çalışanlarına karşı açık sözlü olan, onlara değer veren ve onlarla sağlıklı iletişim kurabilen bir lidere olan güvenin artması beklenmektedir (Yılmaz, 2006). İklimsel etik, etkili bir okul iklimi oluşturmak için çalışanlara sahip çıkılması, onların desteklemesi, düşüncelerin sevgiyi temel alan bir yaklaşımla yayılması, okul kültürünün ve vizyonunun net bir şekilde ortaya konması, çalışanların yaratıcılıklarını maksimum düzeyde ortaya çıkarabilecekleri bir çalışma ortamının hazırlaması ile ilgilidir (Yılmaz, 2005). Davranışsal etik, yöneticinin dürüst ve adil davranışlar sergilemesi, örgütteki herkesi eşit görmesi ve eşit muamele etmesine işaret etmektedir. Ayrıca, mesleğe bağllık, anlayış, inanç, sorumluluk ve başkalarının görüşlerine saygı da etik bir okul yöneticisinden beklenen diğer özelliklerdir (Hughes, 2008). Karar vermede etik, liderin ahlaki açıdan doğru kararlar verebilmesi, doğru ile yanlışı ayırt edebilmesi ve verdiği kararlarda etik davranması kapsamında incelenmektedir (Turhan, 2007).

\section{Örgütsel Bağlılık ve İş Doyumu}

Örgütsel bağlllık işgörenin örgütte kalma ve onun için çaba gösterme arzusu ile örgütün amaç ve değerlerini benimsemesi olarak tanımlanabilmektedir (Morrow, 1983). Örgütsel bağlılık üzerinde çalışmalar yapan Meyer ve Allen, örgütsel bağlllığın psikolojik bir boyuta sahip olduğunu belirterek, işgörenlerin örgütle ilişkisi ile şekillenen ve örgütün sürekli bir üyesi olma kararı almalarını sağlayan bir davranıs olarak tanımlamaktadırlar (Meyer ve Allen, 1991). Meyer ve Allen, örgüte bağlılık alanlarında duygusal, devam ve normatif bağlılık olmak üzere üç alt değişkenin varlı̆̆ını destekleyici çalışmalara ağırlık vermişlerdir. O'Reilly ve Chatman (1986) ise bu kavramı uyum, özdeşleşme ve içselleştirme olmak üzere üç boyutta ele almıştır. Nitekim Türkiye'de yapılan pek çok araștırmada da O'Reilly ve Chatman'ın örgütsel bağlılık sınıflandırmaları kullanılmıştır (Buluç, 2009; Kul ve Güçlü, 2010; Sezer, 2005; Zeren, 2007).

İş doyumu, bireyin yaptı̆̆ 1 iş hakkındaki genel tavrıdır. Araştırmacılar arasında en yaygın olarak kullanılan "iş doyumu tanımları" Hoppock, Locke ve 
Vroom'un tanımlarıdır (Green, 2000). 1930'larda Hoppock'un iş doyumu tanımı, "kişinin gerçekten işimde tatmin oluyorum, demesine sebep olan psikolojik, fizyolojik ve çevresel koşulların karışımıdır" şeklindedir. Locke 1970'lerde iş doyumunu "kişinin işini ve deneyimlerini değerlendirmesinden sonuçlanan haz verici ve olumlu duygular" şeklinde tanımlamıştır. Vroom ise iş doyumunu, "kişinin hâlihazırda işgal ettiği iş rolüne yönelik duygusal yönelimi" olarak tanımlamıştır.

Eğitim örgütlerinin verimliliği ancak öğretmenlerin yaptıkları işten doyum alması ve böylece amaçlar doğrultusunda davranmaya istekli olması ile mümkün olabilmektedir. Örgütteki bireylerin iş doyum düzeyleri, onların fiziksel ve ruhsal sağlığını, örgütün çalışma ortamını ve verimliliğini, toplum huzurunu ve ekonomik gelişmeleri etkileyebilmektedir. Çalı̧anların doyumlarının sağlanması, yönetimin en önemli görevlerinden birisidir. Örgüt içerisinde yaratıcı çözümler üreten, gerekli düzenlemelerle iyileştirmeleri yaparak kurum politikalarını belirleyen liderdir. Sosyal bir sistem olan okulda, öğretmenlerin göstereceği performans, okulun amaçlarının gerçekleştirmesinde en önemli faktörlerden birisidir. Öğretmenlerin moral, motivasyon ve iş doyum düzeyleri öğrenci başarısını ve okulun genel performansını etkilemektedir. Dönüşümcü liderler, paylaşılan vizyon geliştirerek, izleyicilerine sorumluluk vererek, onları motive ederek çalışanların iş doyum düzeylerini de yükseltmektedir (Voon, Lo, Ngui ve Ayob, 2011).

\section{Örgütsel Bağlılık, İş Doyumu ve Etik İlişkisi}

Yöneticinin etik liderlik davranışı, çalışanların örgüte bağglılı̆̆ını ve iş doyumunu olumlu yönde etkileyebilmektedir. Örgütsel bağlllık, örgüte basit bir sadakat değildir. Örgütün amaç ve değerlerini benimseme, örgüt için büyük çaba göstermeye istekli olma ve örgütte kalma isteğidir (Cohen, 2007). Allen ve Meyer'e (1990) göre örgütsel bağlılık, çalışanın örgüte olan psikolojik yaklaşımını ifade etmektedir ve işgören ile örgüt arasındaki ilişkiyi yansıtan, örgüt üyeliğini devam ettirme kararına yol açan psikolojik bir durumdur.

İsgörenlerin örgüte bağlılık hissetmesi, kendi iş verimlerini artırarak örgüt için olumlu sonuçlar doğurmaktadır. Dolayısıyla bir örgütün, işgörenlerin örgüte bağlılığını artırabilecek ya da azaltabilecek faktörlerin farkında olması önemli bir husus olarak karşımıza çıkmaktadır. Bu nedenle örgütsel bağlılığ etkileyen ve belirleyen faktörlerden birisi de yöneticilerin liderlik davranışlarıdır (Balay, 2000; Çetin, 2004).

Örgütsel bağlılığı belirleyen faktörler, örgüt yapısı, örgüt kültürü, ücret düzeyi, işin niteliği ve önemi, liderlik, örgütsel adalet, rol belirsizliği, çatışma ve ait olma ihtiyacı gibi değişkenlerdir. Ayrıca yöneticilerin etik liderlik özellikleri çalışanların adalet algısı ve bu dolayımla örgütsel bağlılıkları üzerinde etkili olabilmektedir (Uğurlu, 2009). Liderlik, yöneticinin çalışanlar ile iletişim kurma ve onları harekete geçirmede kullandığı yöntemi belirlemektedir (Smadov, 
Canan Madenoğlu, Şengül Uysal, Yllmaz Sarter \& Köksal Banoğlu

2006). Yöneticinin liderlik özellikleri örgütsel değerlere ve hedeflere bağlılığı etkilemektedir.

Okul yöneticinin etik liderlik davranışlarının öğretmenlerin iş doyumunu etkilediği de bilinmektedir. Nitekim Eroğlu'na (1998) göre iş doyumunun öğretmenlerin okulun amaçlarına ulaşmadaki katkılarını arttıran en önemli faktör olduğu söylenebilir. Öğretmenlerin davranışlarının yönlendirilmesi açısından okul yöneticisinin liderlik davranışları büyük önem taşımaktadır. Çünkü okul yöneticisinin liderlik gücü ile öğretmenlerin iş doyumu ve performans düzeyleri arasında yakın bir ilişki vardır (Çelik, 2003).

İş doyumu, bir kişinin işinden kaynaklanan olumlu ya da keyif verici duygusal durum olarak tanımlanabilir. Buna benzer olarak, Schermerhorn, Hunt ve Osborn (1994) iş doyumunu "kişilerin işleri hakkında olumlu ya da olumsuz hislerinin derecesidir" şeklinde tanımlamışlardır. Kişinin işine, fiziki ve sosyal şartlara karşı bir duygusal cevabı olarak ele alınan iş tatmini kavramı, kişinin işinden beklediklerinden ne kadar tatmin olduğunun bir göstergesidir (Schermerhorn, Hunt ve Osborn, 1994). Locke'a (1976) göre iş doyumu, bir kimsenin işi veya işteki deneyimleriyle ilgili değerlendirmeleri sonucunda ortaya çıkan olumlu ve hoşa giden duygusal durumlardır. "İş tutumları" ve "iş doyumu" kavramlarını birbirinin yerine kullanan Vroom'a (1982) göre iş doyumu, "bireylerin halen meşgul oldukları işteki rolleriyle ilgili duygusal yönelimleridir" (akt. Green, 2000). Duygusal özelliklerle ilişkili olabilecek bir diğer etken cinsiyet faktör ve aile yaşantısıdır ve araştırmalarda bu değişkenlerin de çalışanların örgütsel bağlılığı üzerinde etkili olduğu görülmüsstür (Aven, Parker ve McEnvoy, 1993; Dixon, Turner, Cunningham, Sagas ve Kent, 2005; Mowday, Steers ve Porter, 1979).

İş doyumu, işe yönelik duygusal bir tepkidir ve sahip olunan işin, beklentileri karşılaması ya da aşması ile belirlenir. Dolayısıyla iş doyumu işin sağladığı olanaklar, ücret, terfi ve yükselme fırsatları, yönetici desteği, iş arkadaşları ve çalışma koşulları gibi bir takım faktörlerin belirlenimi altındadır (Luthans, 1995; May, Korczynski ve Frenkel, 2002). Bu nedenle örgütsel değerler de çalışanların iş doyumunu etkileyebilmektedir (Tuncer, 1995). İş doyumu yöneticinin işgörene karşı olan tutumuyla yakından ilişkili olup, yöneticinin işgörenlere karşı olumlu tutumu, onlara değer vermesi, yönetici ve işgören arasındaki olumlu ilişkiler işgörenin yaptığı işten doyum sağlamasına neden olabilmektedir (Bölüktepe, 1993).

\section{Araştırmanın Amacı}

$\mathrm{Bu}$ çalışmada etik liderlik ve iş doyumu değişkenlerinin örgütsel bağlllık üzerindeki yordama düzeyi araştırılmıştır. Bugüne kadar yapılan pek çok araştırmada iş tatmini ve örgütsel bağlllık değişkenlerini etkileyen faktörler incelenmiş olup; konuyla ilgili mevcut literatür etik liderlik, örgütsel bağlılık ve iş doyumu arasında teorik anlamda bir ilişki bulunduğunu ve söz konusu 
ilişkinin örgütsel değişkenlerin açıklanmasında önemli bir yere sahip olduğunu işaret etmektedir (Akınaltuğ, 2003; Kırel, 1999; Kömürcüoğlu, 2003; Yüksel, 2003). Örneğin, Poyraz ve Kama'nın (2008) araştırma sonucuna göre örgütsel bağlılık, iş tatminini olumlu yönde etkilerken; iş tatmini de örgütsel bă̆glılı̆̆ aynı yönde etkilemektedir. Başka bir ifadeyle iş tatmini yüksek olan çalışanlar örgütlerine daha fazla bağlı olma eğilimi gösterirken; iş tatmini düşük olan çalışanlar ise örgüte zarar verebilecek davranış gösterme eğilimindedirler. Bununla ilişkili olarak Sharma ve Bajpai (2010) örgütsel bağlılığın, iş tatmininin öncülü ve belirleyici özelliklerinden biri olduğunu ifade etmiştir.

$\mathrm{Bu}$ araştırma konuyu eğitim örgütleri özelinde incelemiştir. Bu nedenle araştırmanın amacı: ortaöğretim okullarında görev yapan okul müdürlerinin etik liderlik düzeyleri ile öğretmenlerin iş doyumunun, örgütsel bağlılı̆̆ yordama düzeyini ortaya koymaktır. Bu amaca yönelik olarak araştırmada şu sorulara cevap aranmıştır:

1. Okul müdürlerinin algılanan etik liderlik düzeyi öğretmenlerin örgütsel bağlılık düzeyinin açıklanmasında anlamlı bir yordayıcı mıdır?

2. Okul müdürlerinin etik liderlik düzeyi ve öğretmenlerin sahip olduğu iş doyumu, öğretmenlerin örgütsel bağlılık düzeyinin açıklanmasında anlamlı bir yordayıcı midir?

3. Okul müdürlerinin etik liderlik düzeyi, öğretmenlerin sahip olduğu iş doyumu, cinsiyet, medeni durum, çalıştıkları okul türü (Anadolu lisesi/meslek lisesi), öğretmenlik alanı (meslek öğretmeni/kültür öğretmeni), eğitim durumu (lisans/lisansüstü) demografik değişkenleriyle birlikte, öğretmenlerin örgütsel bağlılık düzeyinin açıklanmasında anlamlı bir yordayıcı mıdır?

4. Okul müdürlerinin etik liderlik düzeyi, öğretmenlerin sahip olduğu iş doyumu, cinsiyet, medeni durum, çalıştıkları okul türü (Anadolu lisesi/meslek lisesi), öğretmenlik alanı (meslek öğretmeni/kültür öğretmeni), eğitim durumu (lisans/lisansüstü) demografik değişkenleri ve öğretmenlik kıdemleri öğretmenlerin örgütsel bağlılık düzeyinin açıklanmasında anlamlı bir yordayıcı midır?

5. Öğretmenlerin örgütsel bağll1ık düzeyinin yordanmasında etik liderlik ya da iş doyumu değişkenleri aracı değişken özelliği göstermekte midir?

Yürütülen araştırmanın iki yönden mevcut literatüre katkı sağlaması beklenmektedir. Birincisi, hiyerarşik regresyon analizi sayesinde etik liderlik ve iş doyumu değişkenleriyle birlikte demografik değişkenler de kukla değişken (dummy) olarak regresyon denklemine dâhil edilmiş, bu sayede bağımsız değişkenlerin her basamakta örgütsel bağlılık bağımlı değişkenini yordama düzeyleri adım adım incelenmiştir. İkincisi, bu hiyerarşik yaklaşım sayesinde elde edilen regresyon katsayıları her basamakta karşılaştırılarak etik liderlik ve iş doyumu düzeyleri için temel-aracı değişken analizi gerçekleştirilmiştir. $\mathrm{Bu}$ yönleriyle araştırmanın özgün sonuçlar ortaya koyduğu düşünülmektedir. 


\section{Yöntem}

Araştırma ilişkisel tarama modeline dayanan betimsel bir çalışmadır. Tarama modeli geçmişte ya da hala var olan bir durumu olduğu şekliyle betimlemeyi amaçlayan bir yaklaşımdır (Karasar, 2006).

\section{Evren ve Örneklem}

Araştırmanın evrenini, 2011-2012 eğitim-öğretim yılında, Eskişehir ili merkez ilçelerinde (Odunpazarı ve Tepebaşı) akademik (Anadolu ve genel liseler) ile mesleki (kız ve erkek) liselerde görev yapan öğretmenler oluşturmaktadır. Çalışmada belirlenen tüm evrene ulaşılması hedeflendiği için örneklem belirlenmemiştir. Bu bağlamda çalışma kapsamına, 27'si akademik lise ve 9'u meslek lisesi olmak üzere toplam 36 ortaöğretim kurumu alınmıştır. Anket uygulaması sonucunda eksiksiz dönüs sağlanan 31 okulda (23 akademik lise ve 8 meslek lisesi) analize dahil edilmiştir. İl Milli Eğitim Müdürlüğü’nün verileri dikkate alınarak toplam 1220 anket formu okullara gönderilmiştir. Geri dönen formların değerlendirilmesi sonucunda anketlerin 940 tanesinin kullanılabilir nitelikte olduğu görülmüştür.

Tablo 1

Katılımcılara IIlişkin Kişisel Bilgiler

\begin{tabular}{llcc}
\hline Değişkenler & & $n$ & $\%$ \\
\hline \multirow{2}{*}{ Cinsiyet } & Erkek & 385 & 41.0 \\
\multirow{3}{*}{ Medeni Durum } & Kadın & 555 & 59.0 \\
& Bekar & 160 & 17.0 \\
& Evli & 780 & 83.0 \\
Kıdem & $1-5$ yıl & 58 & 6.2 \\
& $6-10$ yıl & 102 & 10.9 \\
& $11-15$ yıl & 328 & 34.8 \\
Eğitim Durumu & $16-20$ yıl & 251 & 26.7 \\
& 21 yıl ve üstü & 201 & 21.4 \\
Okul Türü & Ön lisans & 12 & 1.3 \\
& Lisans & 789 & 83.9 \\
Ö̈̆retmenlik Grubu & Yüksek Lisans & 139 & 14.8 \\
& Akademik Lise & 552 & 58.7 \\
& Meslek Lisesi & 388 & 41.3 \\
& Kültür Öğretmeni & 787 & 83.7 \\
Beslek Dersi & 153 & 16.3 \\
& Öğretmeni & 422 & 44.9 \\
& Sözel & 311 & 33.1 \\
\hline & Sayısal & 53 & 5.6 \\
\hline
\end{tabular}

\section{Ölçme Araçları}

Veri toplama aracı olarak Yılmaz (2006) tarafından geliştirilen etik liderlik ölçeği, Üstüner (2009) tarafından geliştirilen örgütsel bağlılık ölçeği ve Yıldırım 
(2001) tarafından geliştirilen iş doyum ölçeği kullanılmıştır. Kullanılan ölçekler için Eskişehir İl Milli Eğitim Müdürlüğü’nden gerekli izinler alınmıştır. Ölçeklerin güvenirlik düzeyini tekrar analiz etmek için, en fazla madde içeren etik liderlik ölçeği referans alınarak (44 madde $* 5=220$ den fazla olacak şekilde) 300 öğretmen ile bir ön çalışma yürütülmüştür. Bu bağlamda kullanılan ölçeklere ilişkin ön test iç tutarlık güvenirlik katsayıları (Cronbach's Alpha) Tablo 2'de verilmiştir.

Tablo 2

Ölçeklerin Güvenilirlik Dağılımı

\begin{tabular}{lccc}
\hline & $\begin{array}{c}\text { Etik Liderlik } \\
\text { (Yılmaz, 2006) } \\
44 \text { madde }\end{array}$ & $\begin{array}{c}\text { Örgütsel Bağlılık } \\
\text { (Üstüner, 2009) } \\
17 \text { madde }\end{array}$ & $\begin{array}{c}\text { İs Doyumu } \\
\text { (Yıldırım, 2001) } \\
15 \text { madde }\end{array}$ \\
\hline $\begin{array}{l}\text { Ölçeğin geliştiricilerinin } \\
\text { hesapladığı güvenirlik } \\
\text { değeri }\end{array}$ & .97 & .96 & .88 \\
\hline $\begin{array}{l}\text { Bu çalışmada hesaplanan } \\
\text { güvenirlik değeri }\end{array}$ & .99 & .98 & .94 \\
\hline
\end{tabular}

Üç ölçeğin bir arada uygulandığı ve toplamda 76 maddeden oluşan anket formu beşli Likert tipindedir. Her maddeye verilecek cevap kodları 1 ile 5 arasında değişmektedir. Dereceleme maddeleri "1-Hiç Katılmıyorum, 2Katılmıyorum, 3-Kısmen Katılıyorum, 4-Katılıyorum, 5-Tamamen Katılıyorum" seçeneklerinden oluşmaktadır.

\section{Verilerin Analizi}

Regresyon analizi temel varsayımları karşılandığı zaman güçlü bir istatiksel kestirim yöntemidir (Tabachnick ve Fidell, 2007). Bu varsayımlar uç değerlerin veri setinden çıkartılması, değişkenler arasında çoklu bağlantılılık ve otokorelasyon probleminin bulunmaması, normallik, doğrusallık ve hata varyanslarının eşit dağılımıdır (Field, 2005; Tabachnick ve Fidell, 2007).

$\mathrm{Bu}$ nedenle araştırma ön analizler ve temel analizler olmak üzere iki aşamada gerçekleştirilmiştir. Birinci aşamada ölçme araçlarından toplanan verilerin normallik, çoklu normallik, doğrusallık, hata varyanslarının dağılımı, otokorelasyon ve çoklu bağlantılılık durumu incelenmiştir. Bu incelemeler sonrasında uç değerlerin çıkarımı ve dönüştürme işlemleri kullanılarak veri setleri hiyerarşik regresyon analizine hazır hale getirilmiştir.

İkinci aşamada yordamsal istatistiklerden hiyerarşik regresyon analizi kullanılarak, dört basamakta bağımsız değişkenler ile bağımlı değişken arasındaki yordayıcılık ilişkisi incelenmiştir. Verilerin analizinde SPSS 16.0 paket programı kullanılmıştır. 
Canan Madenoğlu, Şengül Uysal, Yılmaz Sarter \& Köksal Banoğlu

\section{Ön Analizler}

Verilere ait çarpıklık ve basıklık değerleri uç değer analizleri ve dönüştürme işlemlerine bağlı olarak tablolaştırılmıştır.

Tablo 3

Ön Analiz Öncesi ve Sonrası Çarpıklık ve Basıklık Değerleri

\begin{tabular}{|c|c|c|c|c|}
\hline \multicolumn{2}{|c|}{ Çarpıklık ve Basıklık Değerleri } & \multirow{2}{*}{$\begin{array}{c}\text { Etik Liderlik } \\
940\end{array}$} & \multirow{3}{*}{$\begin{array}{c}\text { Örgütsel Bağlllık } \\
940 \\
-370\end{array}$} & \multirow{2}{*}{$\frac{\dot{I}_{S} \text { Doyumu }}{940}$} \\
\hline \multirow{7}{*}{ Başlangıç Veri Seti } & $N$ & & & \\
\hline & Skewness & -.890 & & -.573 \\
\hline & S.H. & .080 & .080 & .080 \\
\hline & $Z$ & 11.15 & 4.63 & 7.19 \\
\hline & Kurtosis & .404 & -.591 & -.174 \\
\hline & S.H. & .159 & .159 & .159 \\
\hline & $Z$ & 2.53 & 3.71 & 1.09 \\
\hline \multirow{7}{*}{ Uç Değer Analizi Sonrası } & $N$ & 869 & 869 & 869 \\
\hline & Skewness & -.496 & -.250 & -.393 \\
\hline & S.H. & .083 & .083 & .083 \\
\hline & $Z$ & 5.98 & 3.01 & 4.74 \\
\hline & Kurtosis & -.472 & -.731 & -.459 \\
\hline & S.H. & .166 & .166 & .166 \\
\hline & $Z$ & 2.85 & 1.00 & 2.77 \\
\hline \multirow{7}{*}{$\begin{array}{l}\text { Dönüştürme İşlemi } \\
\text { (Kare Alma) Sonrası }\end{array}$} & $N$ & 869 & 869 & 869 \\
\hline & Skewness & -.155 & .192 & .019 \\
\hline & S.H. & .083 & .083 & .083 \\
\hline & $Z$ & 1.87 & 1.00 & 0.23 \\
\hline & Kurtosis & -.905 & -.906 & -.661 \\
\hline & S.H. & .166 & .166 & .166 \\
\hline & $Z$ & 5.46 & 1.00 & 3.99 \\
\hline
\end{tabular}

Tablo 3'teki bulgularda başlangıç veri setinin tüm boyutlarda aşırı derecede sağa çarpık olduğu ve skewness çarpıklık değerlerinin standart çarpıklık hata değerlerine oranlarının ( $\mathrm{z}$ değerleri) 4.63 ile 11.15 arasında değiştiği görülmektedir. Bu nedenle her üç veri setinden söz konusu çarpıklığa neden olan uç değerler elemine edilmiştir. Uç değer analizi sonrasında örneklemdeki 71 uç değer tespit edilerek veri setinden çıkartılmıştır. Böylece veri setlerine ait çarpıklık z değerleri 3.01 ile 5.98 aralığına çekilmiştir. Tabachnick (2007) ve Field (2005)'a göre büyük veri setlerinde standart hata değerleri küçüldüğü için z değerlerinin büyümesi normal karşılanmaktadır. Ancak bir kural olarak z değerlerinin 3'ü geçmesi normal dağılım açısından bir sorun olarak görülmektedir. Böyle durumlarda çarpıklığın yönüne bağlı olarak veri setlerine 
uygun dönüştürme (transformation) işlemi uygulanır (Çokluk, Şekercioğlu, Büyüköztürk, 2010; Fidel, 2009; Tabachnick ve Fidell, 2007).

Tablo 3'te dönüştürme işlemi sonrasında çarpıklık z değerinin .23 ile 1.87 aralı̆̆ında değiştiği göstermektedir. Logaritmik, ters işlem ve kare alma dönüştürme işlemleri sonucunda kare alma dönüştürme işleminin veri setinin çarpıklığını eşik z değeri olarak kabul edilen 2'nin altına çektiği görülmüştür. Basıklık değerleri dönüştürme işlemi sonrasında bir miktar artmakla birlikte, bulgular kurtosis basıklık katsayısının her üç veri seti için de eşik değer olarak kabul edilen +2 ve -2 aralığında olduğunu göstermektedir. Bu sonuçlara bağlı olarak veri setinin normal dağılım özelliğine sahip olduğu tespit edilmiştir.

Dönüştürme işlemleri sonrasında veri setlerinin çoklu normallik özellikleri çoklu dağııım Mahalonobis uzaklık değeri katsayısı ve saçılım diyagramı kullanılarak incelenmiştir. Field (2005)'a göre Mahalonobis uzaklık katsayı değeri çoklu normal dağılım özelliği açısında 500 ve üzeri örneklem büyüklüğ̈̈ ve 5'ten fazla bağımsız değişkenin bulunduğu regresyon denklemlerinde eşik değer olarak kabul edilen 25'i aşmamalıdır. Analiz sonucunda en yüksek mahalonobis katsayısının 23.251 olduğu tespit edilmiştir. Ayrıca saçılım diyagramında verilerin uç değer içermediği doğrusallık özelliği gösterdiği ve hata varyanslarının homojen dağıldığı belirlenmiştir.

Çoklu bağlantılılık varsayımı için önce değişkenler arasındaki Pearson ilişki katsayısı incelenmiştir. Çokluk, Şekercioğlu ve Büyüköztürk (2010)'e göre değişeknler arasında .90 ve üzeri korelasyon ilişkisinin varlığ çoklu bağlantı problemine dikkat çekmektedir. Bu araştırmanın verileri arasındaki korelasyon değerleri .577-.749 aralığında değişmektedir. Çoklu bağlantılılık durumu ayrıca regresyon analizi kapsamında VIF ve Tolerans değerlerine bakılarak da incelenmiştir. Analiz sonuçları değişkenlerin VIF değerlerinin 1.067-4.814 aralı̆̆ında değiştiğini ve aşılmaması gereken eşik olarak kabul edilen 10 değerinin oldukça altında olduğunu göstermiştir. Benzer şekilde Tolerans değerinin de eşik değer kabul edilen .10'nun oldukça üstünde, .208-.937 aralığında değiştiği görülmüştür (Tabachnick, 2007).

Değişkenler arasındaki otokorelasyon durumu Durbin-Watson katsayısına bakılarak incelenmiş ve katsayının eşik değer aralığı olarak kabul edilen 1.5-2.5 aralığında 1.944 olduğu belirlenmiştir (Field, 2005). Söz konusu ön analizler sonucunda temel regresyon analizi varsayımlarının karşılandığı tespit edildiğinden hiyerarşik regresyon analizine geçilmiştir.

\section{Bulgular}

Hiyerarşik regresyon analizi sırasıyla ilk dört araştırma sorusuna karşllk gelecek şekilde dört basamakta uygulanmıştır. Bu basamaklar ve içerdikleri değişkenler şöyledir: 
- IIlk basamakta, örgütsel bağlllık değişkeni üzerinde okul müdürlerinin etik liderlik düzeyinin yordayıcıllğ̆ incelenmiştir.

- İkinci basmakta, etik liderlik değişkenine ek olarak öğretmenlerin iş doyumu değişkeni de regresyon denklemine dâhil edilmiştir.

- Üçüncü basamakta, ilk iki basamağa ek olarak öğretmenlere ait iki kategorili demografik değişkenler (cinsiyet, medeni durum, okul türü, öğretmenlik alanı, eğitim durumu) regresyon denklemine dâhil edilmiştir.

- Dördüncü ve son basamakta 5 kategorili öğretmenlik kıdemi değişkeni iki kategorili yapay değişkenler (dummy variables) haline dönüştülerek regresyon analizine dâhil edilmiştir.

Regresyon analizi öncesinde değişkenler arasındaki korelasyon değerlerinin .32-.68 aralığında değiştiği veri setindeki değişkenler arasında .90 ve üstü düzeyde yüksek korelasyon bulunmadığ tespit edilmiştir. Regresyon analizinin sonuçları aşă̆ıdaki tabloda sunulmuştur.

Tablo 4

Etik Liderlik, İs Doyumu ve Demografik Değisskenlerin Örgütsel Bağlllik Düzeyini Yordama Regresyon Analizi Sonuçlart

\begin{tabular}{|c|c|c|c|c|c|c|c|c|c|}
\hline \multicolumn{2}{|c|}{ Bă̆ımsız Değişkenler } & $\beta$ & $t$ & $p$ & $R$ & $R^{2}$ & Düzeltilmiş $R^{2}$ & $F$ & $p$ \\
\hline \multicolumn{2}{|c|}{ Etik Liderlik } & .495 & 21.526 & $.000 *$ & .749 & .561 & .560 & 1107.025 & $.000^{*}$ \\
\hline \multicolumn{2}{|c|}{ İş Doyumu } & .436 & 18.317 & $.000 *$ & .836 & .699 & .698 & 1005.823 & $.000^{*}$ \\
\hline \multicolumn{2}{|l|}{ Cinsiyet } & -.063 & -3.316 & $.001^{*}$ & & & & & \\
\hline \multicolumn{2}{|c|}{ Medeni durum } & -.009 & -.487 & .626 & & & & & \\
\hline \multicolumn{2}{|c|}{ Okul Türü } & -.051 & -2.281 & $.023^{*}$ & .841 & .708 & .705 & 297.646 & $.000 *$ \\
\hline \multicolumn{2}{|c|}{ Öğretmenlik Alanı } & .026 & 1.183 & .237 & & & & & \\
\hline \multicolumn{2}{|c|}{ Eğitim durumu } & -.035 & -1.865 & .062 & & & & & \\
\hline \multirow{4}{*}{$\begin{array}{l}\text { Kıdem } \\
\text { Durumu }\end{array}$} & $6-10$ yıl arası & .014 & .492 & .623 & \multirow{4}{*}{.842} & \multirow{4}{*}{.709} & \multirow{4}{*}{.706} & \multirow{4}{*}{190.099} & \multirow{4}{*}{$.000 *$} \\
\hline & $11-15$ yıl arası & -.036 & -.896 & .370 & & & & & \\
\hline & $16-20$ yıl arası & .002 & .046 & .963 & & & & & \\
\hline & 21 yll ve üstü & -.004 & -.118 & .906 & & & & & \\
\hline
\end{tabular}

Tablo 4'teki bulgularda regresyon denklemindeki her basamakta okul müdürlerinin etik liderliği $\left(\mathrm{F}_{(1,867)}=1107.205 ; p<.01\right)$, öğretmenlerin iş doyumu $\left(\mathrm{F}_{(2,866)}=1105.823 ; p<.01\right)$, cinsiyet, medeni durum, okul türü, öğretmenlik alanı, eğitim durumu $\left(\mathrm{F}_{(7,861)}=297.646 ; p<.01\right)$ ve kıdem bağımsız değişkenlerinin $\left(\mathrm{F}_{(11,857)}=190.099 ; p<.01\right)$ model bazında öğretmenlerin örgütsel bağlılık düzeyinin yordanmasına katkı sağladığı ve tüm değişkenlerin dâhil olduğu son basamağın oluşan toplam varyansın \%71'ini açıklayabildiği görülmektedir $\left(R^{2}=.709\right)$.

Ancak söz konusu $\mathrm{F}$ değerleri değişkenlerin değil modellerin oluşturduğu varyans farkının anlamlılı̆̆ını göstermektedir. Bu nedenle her değişkenin denklem üzerindeki yordama düzeyini belirleyebilmek için beta değerlerinin 
anlamlılığı incelenmelidir (Field, 2005; Tabachnick ve Fidell, 2007). Bu değerler incelendiğinde en büyük yordayıcılı̆̆ın etik liderlik $(\beta=.495 ; p<.01)$ ve iş doyumu $(\beta=.436 ; p<.01)$ değişkenlerine ait olduğu görülmüştür.

Öte yandan cinsiyet $(\beta=-.063 ; p<.05)$ ve okul türü $(\beta=-.051 ; p<.05)$ değişkenlerinin ise regresyon denklemine negatif yönde ve çok küçük bir katkı sağladığı belirlenmiştir. Cinsiyet ve okul türü değişkenleri alt kategorileri doğrultusunda değerlendirildiğinde, öğretmenin kadın olması (analizde 1 olarak kodlanmıştır) ve okul türünün meslek lisesi olması (analizde 1 olarak kodlanmıştır), iş doyumu artış gösterse bile örgütsel bağlılık düzeyinin daha düşük bir değerde yordanmasında etkili olmaktadır. Diğer bir ifadeyle erkek ve Anadolu lisesinde çalı̧san öğretmenlerin, iş doyumu ve müdürlerinin etik liderlik düzeyine ilişkin algıları arttığı oranda söz konusu öğretmenlerin örgütsel bağlılık düzeylerinde de bir artış olacağı $\% 1$ hata aralığında yordanabilmektedir.

Dördüncü basamak analizde, regresyon denklemine dâhil edilen kıdem değişkenlerinin denkleme anlamlı bir katkı sağlamadığı görülmüştür $(p>.05)$. Dolayısıyla dördüncü basamakta oluşan regresyon doğrusuyla bağımsız değişkenlerin ortalama değer doğrusu arasında oluşan varyansa kıdem değişkenlerinin anlamlı bir katkı sağlamadığı belirlenmiştir. Nitekim düzeltilmiş $R^{2} \quad$ değerlerinden anlaşılacağı üzere dördüncü basamakta regresyon denkleminin açıkladığı varyans oranı üçüncü basamağa göre sadece $\% .1$ düzeyinde artmıştır (düzeltilmiş $R^{2}=.706$ ). Yani öğretmenlerin kıdem durumu örgütsel bağlılık düzeylerinin yordanmasına katkı sağlamamaktadır.

Baron ve David (1986) aracı değişkenin belirlenmesinde regresyona dâhil edilen bağımsız değişkenlerin regresyon katsayılarının karşılaştırılması ve bu değerlerdeki düşüşlerin belirlenmesi yoluyla aracı değişkenin tespit edilmesi önerilmektedir. Bu minvalde, iş doyumunun aracı etkisinin anlaşılması için etik liderliğin tek başına alındığı ilk basamak modelle, iş doyumunun da dâhil edildiği ikinci basamak model arasındaki etik liderlik beta değerleri karşılaştırılmıştır. İlk basamakta yüksek bir yordama değerine sahip etik liderliğin $($ Beta $=.749)$ bu değerinin ikinci basamakta düştüğü $($ Beta $=.486)$, ancak ikinci basamakta modelin açıkladığı varyansın \%56'dan \% 70'e yükseldiği görülmüştür. Diğer bir ifadeyle, birinci basamakta örgütsel bağlılığının oluşturduğu varyansın yarısından fazlası (\%56) tek başına okul müdürlerinin etik liderlik davranışları ile açıklanırken $\left(R^{2}=.561\right)$; devamında modele iş doyumu değişkeni eklendiğinde açıklanan varyans oranı \%70'e ulaşmış ancak etik liderliğin yordayıcılığı ilk modele göre azalmıştır. Baron ve David'e (1986) göre aracı değişkenin dâhil edilmesiyle birlikte temel yordayıcılık katsayısında görülen azalma ve açıklanan varyansın artması aracı değişkenin varlığının önemli göstergelerindendir. Nitekim etik liderlik ve iş doyumu değişkenleri arasında yapılan ilişki analizinde, iki değişken arasında orta kuvette ve pozitif yönde ilişki bulunduğu belirlenmiştir $(r=.577 ; p<.01)$. Aynı iki değişkenin 
Canan Madenoğlu, Şengül Uysal, Yllmaz Sarter \& Köksal Banoğlu

yordanan değişken örgütsel bağlllık ile ilişkisi ise $r=.736$ ve $r=.749$ değerindedir $(p<.01)$. Model bazında açıklanan varyansın artması ile beta değerlerindeki düşüş ve söz konusu korelasyon değerleri birlikte değerlendirildiğinde, bu durum okul müdürlerinin etik liderlik davranışlarının temel yordayıcı değişken olduğuna, iş doyumunun ise örgütsel bağllıı üzerinde aracı değişken olduğuna işaret etmektedir. Diğer bir ifadeyle okul müdürlerinin etik liderlik davranışları öğretmenlerin iş doyumunun yordayıcısıyken, bu durum örgütsel bağlılık düzeyinin açıklanmasına da katkı sağlamaktadır.

\section{Tartışma, Sonuç ve Öneriler}

Araştırma sonuçları, öğretmenlerin örgütsel bağlılıklarının etik liderlik ve iş doyumu değişkenleri tarafından yordanabildiğini göstermektedir. Hunt, Wood ve Chonco (1989) etik değerler ile örgütsel bağlılık arasındaki pozitif ve anlamlı ilişkiye dikkat çekmiş; etik değerlerin örgütsel bağlılı̆̆ın güçlü bir öncülü olduğu sonucuna ulaşmıştır. $\mathrm{Bu}$ araştırmadakine benzer bir şekilde, iş doyumu ve örgütsel bağlılık ilişkisinin incelendiği çalışmalarda, iş doyumunun örgütsel bağlılığı, örgütsel bağlılığının da iş doyumunu etkilediği belirlenmiştir (Akınaltuğ, 2003; Kırel, 1999; Kömürcüoğlu, 2003; Yüksel, 2003). Tuncer (1995) işgörenlerin genel olarak işlerinden doyum sağlamalarına karşın, kişisel ve örgütsel değerler sistemindeki farklılıklar nedeniyle örgütsel bağlllık düzeyinde önemli sorunlar yaşandığını tespit etmiştir. Uğurlu (2009) araştırmasında, öğretmenlerin örgütsel bağlllıklarının temelinde, yöneticilerinin etik liderlik davranışları esnasında örgütsel adaleti sağlama davranışlarının bulunduğunu belirtmiştir. Çalışmada, eşitlik, adalet, doğruluk, dürüstlük ve erdem gibi değerlerin ön plana çıkarılması, etik davranışların sergilenebileceği bir okul kültürü ve ikliminin yaratılmasına katkı sağlayacak hizmet içi eğitim çalışmalarına yer verilmesi gibi öneriler geliştirilmiş̧ir.

$\mathrm{Bu}$ nedenle etik liderliğin, öğretmenlerin örgütsel bağllık düzeyini yordaması beklenen bir sonuçtur. Çünkü günümüzde, insanları etkilemek için bürokratik ve yasal otoriteden çok, değer, inanç, duygu ve güven temelli bir liderlik yaklaşımına ihtiyaç duyulmaktadır. Bu bağlamda son zamanlarda vurgulanan etik liderlik; iyiliği yaymaya çalışmak, başkalarına saygı göstermek, dürüstlük, güvenirlilik, samimilik, demokratik karar alma ve katılımı destekleme, anlayışlı olma becerilerinin birleşimi olarak tanımlanabilmektedir (Cuilla, 1998). Etik bir lider, moral ve bürokratik gücü kişiliğinde birleştirmiş, doğruyu tanımlamaya ilişkin değerler ve inançlar sistemi oluşturmuş bir liderdir (Crawford ve Nicklaus, 2000). Etik liderler, izleyicilerin motivasyonlarını, sorumluluk duygularını, örgütsel bağlılıklarını ve örgütsel vatandaşlık davranışları gösterme düzeylerini önemli ölçüde artırmaktadır. İzleyiciler kendilerini destekleyeceklerini ve herkese adaletli davranacaklarını bildikleri etik liderlere güvenmekte, daha fazla karara katılma, sorumluluk alma ve bireysel performanslarını geliştirme eğilimi göstermektedirler. 
Diğer taraftan cinsiyet, okul türü değişkenlerinin yordayıcılığına bakıldığında, erkek ve Anadolu lisesi öğretmenlerin iş doyumu ve okul yöneticilerinin etik liderlik düzeyine ilişkin algı düzeyleri arttığında, öğretmenlerin örgütsel bağlılık düzeyleri de artmaktadır. Sezer (2005), erkek öğretmenlerin kadın öğretmenlere oranla okula daha bağlı olduklarını belirtmiştir. Benzer şekilde bazı araştırmalar da kadınların işe erkeklerden daha az bağlı olduğunu savunmaktadır (Arbak ve Kesken, 2005; Dixon vd., 2005; Yalçın ve İplik, 2005). Bu durumun nedenini bazı araştırmacılar kadınların, kimliklerinin ve tatminlerinin ana kaynağını aile rolleri olarak görmesine dayandırmaktadır (Aven, Parker ve McEnvoy, 1993; Eren, 2004). Dolayısıyla annelik-eşlik rolleri onlar için işlerinden çok daha önemlidir. Ancak erkekler için işleri çok daha önce gelmektedir. Ayrıca kadınlarda işe gelmeme ve işi terk etme olgularına daha sık rastlanılmaktadır. Mowday, Steers ve Porter (1979) ise araştırmalarında kadınların örgütlerinde pozisyonlarını elde etmek için daha zorlu aşamalardan geçtiklerini bu durumun sunucunda bağlılıklarının erkeklere göre daha fazla olduğunu ifade etmişlerdir. Dolayısıyla kadınların erkeklerden farklı güdüleyicilere sahip olmasının iş doyumu ve örgütsel başlılık ilişkisinde etkili olmuş olabileceği yordanabilir.

Araştırmada medeni durum, eğitim durumu ve kıdem değişkenlerinin öğretmenlerin örgütsel bağlılık düzeyinin anlamlı bir yordayıcısı olmadı̆̆ 1 saptanmıştır. Benzer şekilde, Çakır (2007) ve Karagöz (2008), mesleki kıdem ile örgütsel bağlılık arasında anlamlı bir ilişki olmadığını belirtmiştir. Ancak Sezer (2005) kıdemli öğretmenlerin mesleğe yeni başlayan yeni öğretmenlere oranla örgütsel bağlllık düzeylerinin daha yüksek olduğunu belirtmiştir. Benzer şekilde, Danış (2009), çalışma süresi ile doğru orantılı olarak örgütsel bağlılı̆̆ın arttığını belirtmiştir. Karagöz'e (2008) göre, bekâr öğretmenlerin, yöneticilerinin etik liderlik rollerine ilişkin algıları evli öğretmenlere göre daha yüksektir.

Okul yöneticilerinin etik liderlik davranışlarının temel yordayıcı değişken olduğu, iş doyumunun ise örgütsel bağllılı üzerinde aracı değişken olduğu sonucuna ulaşılmıştır. Diğer bir deyişle, okul müdürlerinin etik liderlik davranışları öğretmenlerin iş doyumunu belirlemekte ve bu durum örgütsel bağlılık düzeyinin açıklanmasına da katkı sağlamaktadır. Benzer şekilde Hunt, Wood ve Chonco (1989) araştırmalarında, etik değerler ile örgütsel bağlılık arasında pozitif yönlü ve anlamlı bir ilişkinin bulunduğuna dikkat çekmektedirler. Bu araştırmacılar, etik değerlerin, örgütsel bağlılığı $\% 17\left(R^{2}=\right.$ .170) oranında açıkladığını belirterek, etik değerlerin örgütsel bağlılı̆̆ı güçlü bir önceli olduğu sonucuna ulaşmışlardır. Aynı şekilde Carslon (2005) etik iklim ve örgütsel bağlılık ilişkisini destekleyen bulgulara ulaşmıştır. Dale ve Fox'un (2008) araştırmalarında liderlerin etik liderlik davranışlarının örgütsel bağlılığı anlamlı bir şeklide açıkladığı vurgulanmaktadır. 
Okullar, nitelikli bireylerin yetiştirilebilmesi için öncelikle demokrasi, insan hakları, özgürlük, adalet, sevgi, saygı ve hoşgörü gibi etik değerleri bireylere kazandırmalıdır. Tüm paydaşlar ve özellikle de öğretmenler öncelikle okul müdürlerinden etik liderlik davranışları (adalet, doğruluk, dürüstlük, saygılı olma vb.) sergilemelerini beklemektedir. Bu tür davranışlar göstermeyen okul müdürleri diğer liderlik yaklaşımlarını da etkili bir şekilde kullanamamaktadır. Etik değerlere dikkat etmeyen bir okul müdüründen, dönüşümcü liderliğin vurguladığ paydaşlar için rol model olma, kültürel liderliğin gerektirdiği güçlü bir okul kültürü oluşturma veya demokratik liderliğin temeli olan paydaşların yönetime katılımını gerçekleştirme gibi etkili liderlik davranışları beklenemez. Çalışmada etik liderlik davranışları ile öğretmenlerin iş doyumu ve örgütsel bağlılığı arasında pozitif yönde anlamlı ilişkilerin bulunduğu anlaşılmıştır. Okullarını değiştirmek ve dönüştürmek amacında olan müdürler, öncelikle öğretmenlerin performanslarının artırmak ve onları geliştirmek için etik liderlik davranışları göstermeleri gerektiğini bilmeli ve uygulamalarda bu tür davranışları her fırsatta sergilemelidirler. Eğitim kurumları, etik ve demokratik değerlerin, adaletin, hoşgörünün, işbirliğinin ve sosyal sorumlulukların öğretildiği ortak bir yaşam alanına dönüştürülmelidir. 


\title{
Relationships of School Principals' Ethical Leadership and Teachers' Job Satisfaction on Teachers' Organizational Commitment
}

\author{
Canan Madenoğlu ${ }^{1}$, Şengül Uysal ${ }^{2}, Y_{1}$ ılmaz Sarıer ${ }^{3}$, Köksal Banoğlu$^{4}$
}

Introduction. When the educational management literature are examined, it is seen that there are many leadership areas. "Ethical Leadership" is a kind of leadership which has been discussed by considering the affects of organizational behaviours and management aspects on either individual or organizational output by the educational scientists recently (Dale, Fox, 2008; Karagöz, 2008; Ugurlu, Üstüner, 2011). The importance and the necessity of ethical values of leadership has not become prominent nowadays. According to the wellknown philosopher Spinoza; human-being has been captured by his/her ambitions while they are in their own environments. It is the only way one can be released from this slavery by means of his own intelligence and knowledge. Because of this reason, for Spinoza, behaving with intelligence is nearly same with behaving ethically indeed (Aydın, 2004).

Ethical leaders are helper of the teachers who realize their professional purposes (Çelik, 2003); and so, Greenfield (1991) claimed that ethical leader has a great and strong affect on the teacher who has a moral point of view about himself and his own profession. Johnson (2000)'s study showed that the educational leadership is basically related with the merits about honesty, respect and being respected. Hence, the school managers must have the ethical leadership skills and they have to display them.

The ethical leadership behaviors of the manager may have a great positive impression on the other staff about the loyalty to the organization and job satisfaction. The present literature expresses that there is a theoretical relation between ethical leadership, organizational loyalty and job satisfaction. It also indicates that; this relation occupies an important position in explaining the organizational variances.

Purpose. The purpose of this research is to search out the level of the predictability of relations between the ethical leadership of the school managers, the job satisfaction of the teachers and the levels of the organizational commitment related with the opinions of the teachers, who are

${ }^{1} \mathrm{PhD}$, Salih Zeki Anadolu Lisesi, İstanbul, cmadenoglu@gmail.com, ${ }^{2}$ Eskişehir Osmangazi Üniversitesi, Eskişehir, uysalsengul@yahoo.com.tr, ${ }^{3}$ Eskişehir Osmangazi Üniversitesi, Eskişehir, yilmazsarier@yahoo.com, ${ }^{4}$ İstanbul Halit Armay Anadolu Sağlık Meslek Lisesi, İstanbul, koksal_banoglu@hotmail.com 
Canan Madenoğlu, Şengül Uysal, Yllmaz Sarter \& Köksal Banoğlu

working at the secondary educational schools. For this reason, the answers of the following questions have been searched:

1. To what extent can school principals' perceived ethical leadership forecast teachers' organizational commitment?

2. To what extent can school principals' ethical leadership and teachers' job satisfaction forecast teachers' organizational commitment?

3. To what extent can school principals' ethical leadership, teachers' job satisfaction together with gender, marital status, school type, branches, educational status forecast teachers' organizational commitment?

4. To what extent can school principals' ethical leadership, teachers' job satisfaction together with gender, marital status, school type, branches, educational status and teaching seniority forecast teachers' organizational commitment?

5. Which variance or variances mediate(s) to predict teachers' organizational commitment?

Method. The research was carried out through the relational survey method and the questionnaire application over the research population, that is, secondary school teachers who work in Odunpazarı and Gölbaşı districts in Eskişehir down-town. Since the population was accessible, no sampling method was used to draw a sample from the population in question. After the missing values due to participants were eliminated, out of 1220 teachers, 940 teachers' data were involved in this study.

As for data collection tools, ethical leadership (Yılmaz, 2006), organizational commitment (Üstüner, 2009) and job satisfaction (Yıldırım, 2001) scales were performed.

Initially, preliminary multivariate normality, homogeneity, error variance and linearity analyses were made on first data set and afterwards outlier values were removed. Besides, square root, $\log$ and inverse data transformation procedures were carried out to align data with normality for further hierarchical regression analysis. Secondly, four-step hierarchical regression analysis applied to dependent and independent variables. For computing preliminary and main analyses parameters, SPSS 16 statistical software was used.

Findings. The current research concluded that teacher's job satisfaction $(B=$ $.436 ; p<.01)$ and perception of school principal ethical leadership $(B=.495 ; p$ $<.01)$ predict their organizational commitment $\left(\mathrm{F}_{(1,867)}=1107.205 ; p<.01\right.$; $\left.\mathrm{F}_{(2,866)}=1105.823 ; p<.01\right)$. Furthermore, it was resulted that gender $(B=-$ .063 , in favor of male) and school type ( $B=-.051$, in favor of Anatolian school) variables have influence on organizational commitment, even if just a drop $(p<$ $.05)$. In other words, male and Anatolian school teacher's job satisfaction and 
perception of their principals' ethical leadership can predict their organizational commitment more than female and general secondary school teachers' commitment. Besides, it is found that school principal's ethical leadership was predictor variable over teacher's organizational commitment, wheras job satisfaction was a mediating variable.

Also Hunt, Wood and Chonco (1989)'s study is accordance with the present result that ethical leadership is correlated with organizational commitment to a large extent. Since leaders need to gain trust of their followers, ethical behaviors came into prominence more than their legal authorities. In this context, ethical leadership involves many effective behaviors, such as, for instance, spreading goodness, respecting others, being trustworthy and sincere in interpersonal relations (Cuilla, 1998).

As for the impact of gender and school type variables, the current study showed that when the male Anatolian secondary school teacher's perception of their job satisfaction and ethical leadership of school administrators increases together with their organizational commitment. Also Sezer (2005) had stated that male teachers are more committed to their organizations. Similarly, some researches argue that females are less committed to their organization (Arbak \& Kesken, 2005; Dixon et al., 2005; Yalçın \& İplik, 2005). Mowday, Steers and Porter (1979) express that females try harder to obain positions in organizations and as a result of this situation their commitment level is higher. On the other hand, based on the research results, marital status, education level and seniority variables have no significant effect on the level of teachers' organizational commitment.

At last, it is concluded that the ethical leadership behavior of school principals is the main predictor and job satisfaction is the mediating variable on the organizational commitment. The ethical leadership of school principals affects teachers' job satisfaction and this case contributes to explain the level of organizational commitment. 


\section{Kaynaklar/References}

Akınaltuğ, E. (2003). Yöneticilerde iş stresi, iş doyumu ve örgütsel bağllllk arasındaki ilişkinin incelenmesi: Tedaş örneği (Yayımlanmamış yüksek lisans tezi). Kırıkkale Üniversitesi, Kırıkkale.

Allen, N. J., \& Meyer, J. P. (1990). The measurement and antecedents of affective, continuance and normative commitment to the organization. Journal of Occupational Psychology, 63(1), 1-18.

Amabile, T. M. (1998). How to kill creativity. Harvard Business Review, 76, 77-87.

Arbak, Y. ve Kesken, J. (2005). Örgütsel bağlılık, sağlık hizmetlerinde sürekli gelişim için davranışsal bir yaklaşım. İzmir: Dokuz Eylül Üniversitesi.

Aven, F. F., Parker, B., \& McEnvoy, G. M. (1993). Gender and attitudinal commitment to organizations: A meta analysis. Journal of Applied Psychology, 72, 642-648.

Aydın, A. (2004). Düşünce tarihi ve insan doğası. İstanbul: Gendaş.

Balay, R. (2000). Özel ve resmi liselerde yönetici ve öğretmenlerin örgütsel bağlllğ̆ (Ankara ili örneği) (Yayımlanmamış doktora tezi). Ankara Üniversitesi, Ankara.

Baron, R. M., \& David, A. K. (1986). The moderator-mediator variable distinction in social psychological research: Conceptual, strategic, and statistical considerations. Journal of Personality and Social Psychology, 51(6), 1173-1182.

Bennis, W. (1989). Bir lider olabilmek. Çev. Utku Teksöz. İstanbul: Sistem.

Bölüktepe, F. E. (1993). Kamu örgütlerinde iş tatmini (Yayımlanmamış yüksek lisans tezi). Atatürk Üniversitesi, Erzurum.

Buluç, B. (2009). Sınıf öğretmenlerinin algılarına göre okul müdürlerinin liderlik stilleri ile örgütsel bağlılık arasındaki ilişki. Kuram ve Uygulamada Eğitim Yönetimi, 15(57), 5-34.

Calabrese. R. L. (1988.). Ethical leadership: A prerequisite for effective schools. NASSP Bulletin, 7(512), 1-4.

Crawford. G., \& Nicklaus, J. (2000). Philosophical \& cultural values: Applying ethics in schools. NY: Larchmont, Eye on Education.

Cohen, A. (2007). Commitment before and after: an evaluation and reconceptualization of organizational commitment. Human Resource Management Review, 17, 336-354.

Cuilla, J. B. (1998). Leadership ethics: mapping the territory. In J. B. Cuilla (Ed.), Ethics, the heart of leadership (pp. 3-25). Quorum Books, Westport, CT.

Czaja, M., \& J., Lowe (2000). Preparing leaders for ethical decisions. The AASA Professor, 24(1), 7-12.

Çakır, A. (2007) İlköğretim okullarında görev yapan öğretmenlerin örgütsel bağllllk düzeyleri ve okul kültürü alglar arasindaki iliskinin incelenmesi (Yayımlanmamıs yüksek lisans tezi). Yeditepe Üniversitesi, İstanbul.

Çelik, V. (2003). Eğitimsel liderlik. 3. Baskı. Ankara: Pegem A. 
Çetin, M. (2004). Örgüt kültürü ve örgütsel bağlllk. Ankara: Nobel.

Çırpan, H. (1999). Lider mi? Yönetici mi? Aktive Dergisi, Haziran-Temmuz, 1-5

Çokluk, Ö., Şekercioğlu, G. ve Büyüköztürk, Ş. (2010). Sosyal bilimler için çok değisskenli istatistik. Ankara: Pegem A.

Dale, K., \& Fox, M.L. (2008). Leadership style and organizational commitment: mediating effect of role stres. Journal of Managerial Issues, 20(1) 109-130.

Danış, A. (2009). Anadolu teknik ve anadolu meslek lisesi ögretmenlerinin örgütsel bağllllk düzeyleri (İzmit örneği) (Yayımlanmamış yüksek lisans tezi). Yeditepe Üniversitesi, İstanbul.

Dixon, M. A., Turner, B. A., Cunningham, G. B., Sagas, M., \& Kent, A. (2005). Challenge is key: An investigation of affective organizational commitment in undergraduate interns. Journal of Education for Business, 80, 172-180.

Dobel, J. P. (1998). Political prudence and the ethics of leadership. Public Administration Review, January-February, 74-89.

Eren, E. (2004). Örgütsel davranış ve yönetim psikolojisi. İstanbul: Beta.

Eroğlu, F. (1998). Davranış bilimleri. İstanbul: Beta.

Field, A. (2005). Discovering statistics using SPSS. London: Sage Publication.

Green, J. (2000). Job satisfaction of community college chairpersons (Unpublished doctoral dissertation). Virginia State University, Virginia.

Hameck, D. E. (1970). Leadership styles-decision making and the principal. Selected readings on general supervision. London: Macmillian.

Hipp, K. A., \& Bredeson, P.V. (1995). Exploring connections between teacher efficacy and principal's behavior. Journal of School Leadership, 5(2), 136-150.

Hunt, S. D., Wood, V. R., \& Chonco, L. B. (1989). Corporate ethical values and organizational commitment in marketing. Journal of Marketing, 53(3), 79-90.

Karagöz, A. (2008). İlk ve ortaöğretim okulu yöneticilerinin öğretmenler tarafindan algulanan etik liderlik rolleri ile ögretmenlerin örgütsel adanmışlıkları arasındaki ilişki (Bursa ili örneği) (Yayımlanmamış yüksek lisans tezi). Yeditepe Üniversitesi, İstanbul.

Karaköse, T., \& Kocabaş, İ. (2009). An investigation of ethical culture in educational organizations. African Journal of Business Management, 3(10), 504-510.

Kırel, Ç. (1999). Esnek çalışma saatleri uygulamalarında cinsiyet, iş tatmini ve iş bağlıllı̆̆ ilişkisi. I. Ü. İşletme Fakültesi Dergisi, 28(2), 115-136.

Korkmaz, M. (2007). Örgütsel sağlık üzerine liderlik stillerinin etkisi. Kuram ve Uygulamada Eğitim Yönetimi, (49), 57-91.

Kömürcüoğlu, H. (2003). Belirsizlik ortamında iş tatmini ve işe bağglılık. Endüstri Iliskileri ve Insan Kaynaklar Dergisi, 5(1). Retrieved from http://www.isgucdergi.org

Kul, M. ve Güçlü, M. (2010). Okul yöneticilerinin liderlik stilleri ile beden eğitimi öğretmenlerinin örgütsel bağlılıkları arasındaki ilişki. Uluslararası Insan Bilimleri Dergisi, 7(2), 1021-1038. 
Canan Madenoğlu, Şengül Uysal, Yılmaz Sarter \& Köksal Banoğlu

Lee J. A. (1977). Leader power for managing change. Academy of Management Review, (2), 74-76.

Luthans, F. (1995). Organizational behavior. NY: McGraw-Hill.

May, T. Y., Korczynski M., \& Frenkel, S. J. (2002). Organizational and occupational commitment knowledge workers in large corporations, Journal of Management Studies, 39(6), 775-801.

Meyer, J. P., \& Allen, J. A. (1991). A three-component conceptualization of organizational commitment. Human Resource Management Review, 1(1), 61-89.

Moorhouse, J. R. (2002). Desired characteristics of ethical leaders in business educational political and religious organization from East Tennessee (Unpublished doctoral dissertation). East Tennnessee State University, Tennessee.

Morrow, P. C. (1983). Concept redundancy in organizational research, the case of work commitment. Journal of Occupational Behavior, 34, 40-56.

Mowday, R. T., Steers, R. M., \& Porter, L. W. (1979). The measurement of organizational commitment. Journal of Vocational Behavior, (14), 22-247.

Özden, Y. (2002). Eğitimde yeni değerler. Ankara: PegemA.

Quick, P., \& Normore, A. H. (2004). Moral leadership in the 21 st century: Everyone is watching - especially the students. Kappa Delta Pi, The Educational Forum, 68(4), 336-447.

Poyraz, K. ve Kama, B. (2008). Algılanan iş güvencesinin, iş tatmini, örgütsel bağlılık ve işten ayrılma niyeti üzerindeki etkilerinin incelenmesi. Süleyman Demirel Üniversitesi İktisadi ve İdari Bilimler Fakültesi Dergisi, 13(2), 143-164.

Rahim, M. A. (2004). Leader power, followers' conflict management strategies and propensity to leave a job: a cross-cultural study. Paper presented at the annual conference of the International Association for Conflict Management, PA: Pittsburgh.

Rebore, R. W. (2001). The ethics of educational leadership. Ohio: Merrill Prentice Hall.

Schermerhorn, J.R., Hunt, J.G., \& Osborn, R.N. (1994). Managing organization behavior (5 ed.). NY: John. Willey \& Sons, Inc.

Sezer, F. (2005). Ilköğretim okulu müdürlerinin sergiledikleri liderlik stillerinin ögretmenlerin örgütsel bağlılı̆̆ına etkisi (Yayımlanmamış yüksek lisans tezi). Gazi Üniversitesi, Ankara.

Sergiovanni, T. J., \& Starratt, R.J. (1998). Supervision: a redefinition. Boston: Mcgraw-Hill.

Sharma, J. P., \& Bajpai, N. (2010). Organizational commitment and its impact on job satisfaction of employees: A comperative study in public and private sector in India. International Bulletin of Business Administration, 9, 7-19.

Smadov, S. (2006). İs doyumu ve örgütsel bağlllı: özel sektörde bir uygulama (Yayımlanmamıs yüksek lisans tezi). Dokuz Eylül Üniversitesi, İzmir. 
Tabachnick, B. G., \& Fidell, L. S. (2007). Using multivariate statistics (5th ed.). Boston: Pearson, Allyn \& Bacon.

Thiroux, J. (1998). Ethics theory and practise. NJ: R.R. Donneley\& Sons Company.

Tuncer, A. (1995). MEB bilgisayar eğitimi ve hizmetleri genel müdürlüğü personelinin iş doyumu ve örgütsel bağlllık durumları (Yayımlanmamış lisansüstü uzmanlık tezi). TODAİE, Ankara.

Turhan, M. (2007). Genel ve mesleki lise yöneticilerinin etik liderlik davranışlarının okullardaki sosyal adalet üzerindeki etkisi (Yayımlanmamış doktora tezi). Firat Üniversitesi, Elazığ.

Uğurlu, C. T. ve Üstüner, M. (2011). Öğretmenlerin örgütsel bağlılık düzeylerine yöneticilerinin etik liderlik ve örgütsel adalet davranışlarının etkisi. Hacettepe Üniversitesi Eğitim Fakültesi Dergisi, (41), 434-448.

Uğurlu, C. T. (2009). İlköğretim okulu öğretmenlerinin örğ̈̈tsel bağlllı düzeylerine yöneticilerinin etik liderlik ve örgütsel adalet davranıslarının etkisi (Hatay ili örneği) (Yayımlanmamış doktora tezi). İnönü Üniversitesi, Malatya.

Werner, I. (1993). Liderlik ve yönetim. (Çev. V. Üner). İstanbul: Rota.

Yalçın, A. ve İplik, F. N. (2005). Beş yıldızlı otellerde çalışanların demografik özellikleri ile örgütsel bağlılıkları arasındaki ilişkiyi belirlemeye yönelik bir araştırma: Adana ili örneği. Çukurova Üniversitesi Sosyal Bilimler Enstitüsü Dergisi, 14(1), 395-412.

Yılmaz, E. (2005). Okullarda örgütsel güven ölçeğinin geçerlilik ve güvenirlik çalışması. Selçuk Üniversitesi Sosyal Bilimler Enstitüsü Dergisi, (14), 739-756.

Yılmaz, E. (2006). Okullardaki örgütsel güven düzeyinin okul yöneticilerinin etik liderlik özellikleri ve bazı değişkenler açısından incelenmesi (Yayımlanmamış doktora tezi). Selçuk Üniversitesi, Konya.

Yüksel, İ. (2003). Hemşirelerin iş güçlüğü faktörlerinin belirlenmesi, iş doyumu ve örgütsel bağlılık üzerindeki etkisinin analizi. Marmara Üniversitesi Sosyal Bilimler Enstitüsü Dergisi, 5(20), 131-139.

Zeren, H. (2007). Illköğretim okulu müdürlerinin liderlik stilleri ile bu okullarda görevli ögretmenlerin örgütsel bağlllığı arasındaki ilişki (Yayımlanmamış yüksek lisans tezi). Harran Üniversitesi, Şanlıurfa.

Zhu, W. (2008). The impact of ethical leadership on follower moral identity: The mediating role of psychological empowerment. Leadership Review, (8), 62-73.

Received: 29/04/2013

Revision received: 08/05/2013

Second revision received: 30/01/2014

Third revision received: 21/03/2014

Approved: 24/03/2014 